\title{
Postępowanie kliniczne i wykonawstwo laboratoryjne protez ruchomych z użyciem technologii CAD/CAM - przegląd piśmiennictwa
}

\author{
Clinical and laboratory CAD/CAM procedures and their application in the planning \\ and fabrication of removable dentures - a literature review
}

\author{
${ }^{1}$ Poradnia Protetyki Stomatologicznej, Uniwersytecka Klinika Stomatologiczna w Krakowie \\ ${ }^{2}$ Katedra Protetyki Stomatologicznej, Collegium Medicum UJ
}

DOI: http://dx.doi.org/10.20883/df.2017.24

\begin{abstract}
Streszczenie
Cel. Na podstawie dostępnych badań opublikowanych w piśmiennictwie stomatologicznym na temat protez całkowitych i szkieletowych wytwarzanych w technologii CAD/CAM, przedstawiono sposób ich wykonania w różnych systemach, różnice w poszczególnych etapach klinicznych i laboratoryjnych w porównaniu z metodą konwencjonalną oraz zalety i wady tego rodzaju uzupełnień.

Materiał i metody. Użyto bazy MEDLINE/PubMed, w której wpisano określenia: CAD/CAM complete denture, CAD/ CAM removable partial denture, digital denture. Poszukiwano prac oryginalnych opublikowanych od $1990 \mathrm{r}$. w języku angielskim. Znaleziono 307 publikacji tematycznie powiązanych, których streszczenia zostały przeanalizowane, a następnie wyselekcjonowano 27 artykułów ściśle związanych z tematyką pracy. Do analizy dołączono również dostępne publikacje polskie.

Wyniki. Na podstawie analizy dostępnych artykułów stwierdzono, że technologia CAD/CAM, która od kilkunastu lat znajduje zastosowanie w projektowaniu i wytwarzaniu protez stałych, staje się coraz powszechniej stosowana w przypadku protez ruchomych. Najważniejszymi ośrodkami, które wprowadziły możliwość wykonania uzupełnień metodą CAD/CAM, są: Wieland Dental, Avadent, Dentca, Ceramill. Każda z tych firm przedstawiła odmienny algorytm postępowania klinicznego oraz wykonawstwa laboratoryjnego, który ma na celu zaprojektowanie, a następnie wykonanie cyfrowych protez ruchomych.

Wnioski. Wprowadzenie technologii CAD/CAM do cyfrowego planowania i wytwarzania protez ruchomych umożliwia skrócenie procesu leczniczego w porównaniu z metodą konwencjonalną. Pomimo niewątpliwego skoku technologicznego, jaki obserwujemy w ostatnich kilkunastu latach, związanego z wprowadzeniem nowych systemów (takich jak technologia przyrostowa i subtraktywna), sposób wykonania protez przy ich udziale ma szereg ograniczeń. Ze względu na niewielką obecnie dostępność tej nowoczesnej technologii brak długoczasowych obserwacji klinicznych. Konieczne jest dalsze prowadzenie badań naukowych, które ustalą przydatność technologii CAD/CAM w laboratoryjnym wykonawstwie ruchomych protez zębowych.
\end{abstract}

Słowa kluczowe: protezy częściowe CAD/CAM, protezy całkowite CAD/CAM, protezy cyfrowe.

\begin{abstract}
Aim. Based on the literature about complete and removable partial dentures fabricated using CAD/CAM technology and techniques, as well as differences between the clinical and laboratory steps compared with the conventional method, the advantages and disadvantages of CAD/CAM removable dentures are summarized.

Material and Methods. An electronic search of English language literature was performed using PubMed/MEDLINE for original papers published since 1994 with the following specific search terms: CAD/CAM complete denture, CAD/ CAM removable partial denture, and digital denture. Using a variety of keywords that aimed to narrow the topic, 307 publications were initially searched. For the main topic, the abstracts of these 307 articles were scanned, and 27 publications were selected for reading in detail. The study covered Polish original papers.

Results. Based on the analysis of the available articles, it was found that CAD / CAM technology, which has been used for over a decade in the design and manufacture of fixed prostheses, has become increasingly popular in the case of removable dentures. The most important centres that have introduced the CAD / CAM dentures are Wieland Dental, Avadent, Dentca, and Ceramill. Each of them has introduced a different algorithm for clinical practice and laboratory work that aims to design and make digital prostheses.

Conclusions. Introducing CAD / CAM technology for the digital planning and fabrication of dentures can shorten the treatment process compared with conventional methods. Despite the undoubted technological leap observed in recent years, associated with the introduction of new systems such as additive and subtractive manufacturing, these methods have several limitations. Due to the low availability (only a few companies like Wieland Dental, Avadent, Dentca, and Ceramill fabricate dentures using CAD / CAM), there is no long-term observation of patients who are treated with these dentures. It is necessary to continue research which should ultimately determine the clinical usefulness of CAD / CAM removable dentures.
\end{abstract}

Keywords: CAD/CAM complete denture, CAD/CAM removable partial denture, digital denture. 


\section{Wstęp}

Procedury wykonawstwa laboratoryjnego protez całkowitych uległy niewielkim zmianom na przestrzeni ostatnich 100 lat. Większość artykułów odnoszących się do tych uzupełnień dotyczy konwencjonalnego postępowania obejmującego 5 wizyt klinicznych oraz 5 etapów laboratoryjnych [1]. Technologia CAD/CAM (wspomagane komputerowo projektowanie oraz wytwarzanie), która od kilkudziesięciu lat znajduje zastosowanie w przypadku stałych protez, obecnie umożliwia również projektowanie i wykonywanie protez ruchomych [2]. Niewiele dostępnych publikacji traktuje o wykonawstwie uzupełnień protetycznych tą nowoczesną metodą. Związane jest to ze złożonością etapów klinicznych i laboratoryjnych umożliwiających wykonanie funkcjonalnych protez. Proces przeniesienia wszystkich niezbędnych danych do systemu cyfrowego CAD jest bardziej skomplikowany niż w przypadku protez stałych, gdzie technologia CAD/CAM jest $z$ powodzeniem stosowana od kilkunastu lat. CAM obejmuje m.in. następujące systemy: technologia przyrostowa (ang. additive manufacturing-AM) lub szybkie wykonywanie prototypów (ang. rapid prototyping - RP) - określenie zbioru metod służących do szybkiej, precyzyjnej i powtarzalnej produkcji elementów, zwykle przy sterowaniu komputerowym, powszechnie znanym jako drukowanie 3D, który jest procesem tworzenia przekształcającym model 3D w obiekt rzeczywisty poprzez łączenie ze sobą kolejnych warstw materiału [3]. Należą do nich: stereolitografia oraz technologie: DLP (digital light projection), PolyJet, DMLS (direct metal laser sintering) [4]. Kontrastuje to z większością tradycyjnych technik dotyczących sfery produkcyjnej, takich jak obróbka skrawaniem, które są subtraktywne i polegają na usuwaniu materiału w celu uzyskania końcowego elementu, jak np. w technologii CNC (Computerized Numerical Control). Stwarza ona przedmiot o określonych wymiarach i kształtach pochodzących z obrazu cyfrowego za pomocą frezowania lub szlifowania bloku materiału. Dokładność takiej obróbki wynosi ok. $10 \mu \mathrm{m}$ [5]. Drugą techniką należącą do technologii subtraktywnej jest obróbka elektroerozyjna (EDM - electrical discharge machining), polegająca na korzystaniu z erozji elektrycznej, towarzyszącej wyładowaniom elektrycznym. Pierwsza pionierska publikacja dotycząca wykonania protez całkowitych w technologii CAD/CAM pochodzi z 1994 r. [6], w kolejnych latach opublikowano kilka artykułów, które poruszały tę tematykę [7-10], natomiast pierwsze kliniczne zastosowanie zostało udokumentowane w 2014 r. [11]. Z kolei w 2004 roku Williams i wsp. przedstawili w swoim artykule możliwość zastosowania metody szybkiego proto- typowania (RP) w wykonawstwie szkieletu protezy szkieletowej [12, 13]. W tym samym celu Han i wsp. wykorzystali technologię SLM [14].

\section{Cel}

Celem pracy jest przedstawienie aktualnej wiedzy na temat postępowania klinicznego i wykonawstwa laboratoryjnego protez ruchomych CAD/ CAM, różnic i podobieństw poszczególnych etapów w porównaniu z konwencjonalną metodą oraz określenie zalet i wad tego rodzaju uzupełnień na podstawie piśmiennictwa.

\section{Materiał i metody}

Dokonano analizy piśmiennictwa z lat 1990-2017. W tym celu wykorzystano medyczną bazę danych PubMed, używając następujących słów kluczowych: „CAD/CAM complete denture”, „CAD/CAM removable partial denture”, „digital denture”. Poszukiwano prac w języku angielskim. Znaleziono 307 publikacji tematycznie powiązanych, których streszczenia zostały przeanalizowane, a następnie wyselekcjonowano 27 artykułów ściśle związanych z tematyką pracy. Do analizy włączono dostępne publikacje polskie.

\section{Protezy całkowite CAD/CAM}

Współcześnie na świecie tym zagadnieniem zajmuje się kilka ośrodków techniki laboratoryjnej CAD/CAM. Najpopularniejsze to: Wieland dental, Avadent, Dentca, Ceramill. Pierwszy i drugi używają technologii subtrakcyjnej do skrawania płyty protezy z wcześniej spolimeryzowanego krążka żywicy akrylowej, natomiast trzeci posługuje się techniką addytywną - szybkiego wykonywania prototypów (stereolitografii) do tworzenia protezy próbnej, która po akceptacji stomatologa jest dalej wykonywana za pomocą konwencjonalnej metody puszkowania [15]. Ceramill w odróżnieniu od pozostałych to system przeznaczony do pracy w laboratorium, nie wymagający od lekarza specjalistycznego instrumentarium.

\section{Digital Denture System (Wieland Dental, Ivoclar Vivadent)}

Etapy kliniczne są zbliżone do postępowania z zastosowaniem Biofunkcjonalnego Systemu Protetycznego (BPS) [16]. Różnice wynikają z wykorzystania odmiennych procedur laboratoryjnych [17].

Opis poszczególnych etapów klinicznych i laboratoryjnych:

\section{Wizyta kliniczna}

Obejmuje wywiad, badanie kliniczne, ustalenie planu leczenia. Pobierane są wyciski anatomiczne szczęki i żuchwy przy pomocy tzw. nośnika 
zwarcia (centric tray) (Rycina 1) przy ustach zamkniętych, co umożliwia odwzorowanie pola protetycznego górnego i dolnego wyrostka zębodołowego oraz wstępną relację żuchwy do szczęki. Wysokość zwarcia jest ustalana za pomocą metod konwencjonalnych (np. anatomofizjologicznej) bądź odtwarzana z poprzednich protez, gdy są one we właściwej wysokości. Masa alginatowa nakładana jest obustronnie na nośnik zwarcia. Po jej wprowadzeniu do jamy ustnej poleca się pacjentowi zamykanie ust do wcześniej zarejestrowanej wysokości zwarciowej. Na tym etapie producent zaleca również rejestrację płaszczyzny protetycznej względem osi zawiasowej stawu skroniowo-żuchwowego za pomocą łuku twarzowego UTS CAD (Rycina 2), który montowany jest do nośnika zwarcia. Umożliwia on pomiar kątów pomiędzy płaszczyzną zwarcia a linią Campera (CP) oraz linią międzyźreniczną (BP). Te wartości oraz wyciski anatomiczne szczęki i żuchwy na nośniku zwarcia przesyłane są do laboratorium.

\section{Etap laboratoryjny}

Zaletą w przeciwieństwie do metod tradycyjnych jest to, że etap ten nie wymaga tradycyjnego odlewania modeli oraz ich artykulacji. Te czynności

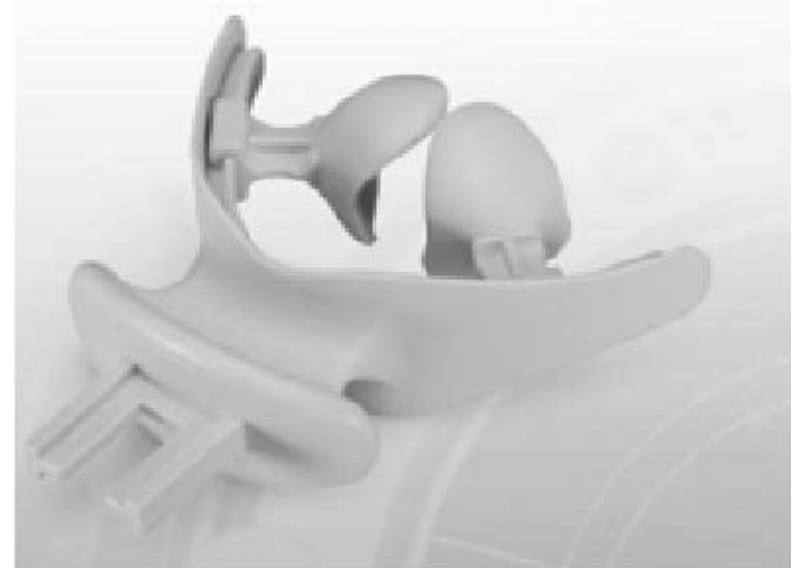

Rycina 1. Nośnik zwarcia

Figure 1. Centric Tray

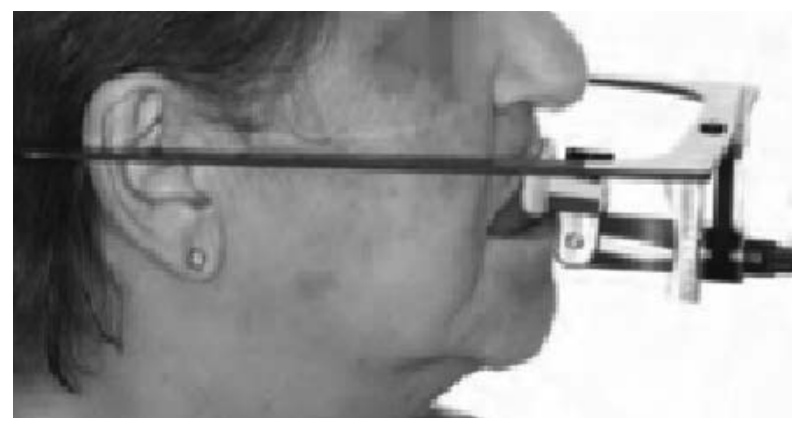

Rycina 2. Łuk twarzowy UTS CAD

Figure 2. Facebow UTS CAD

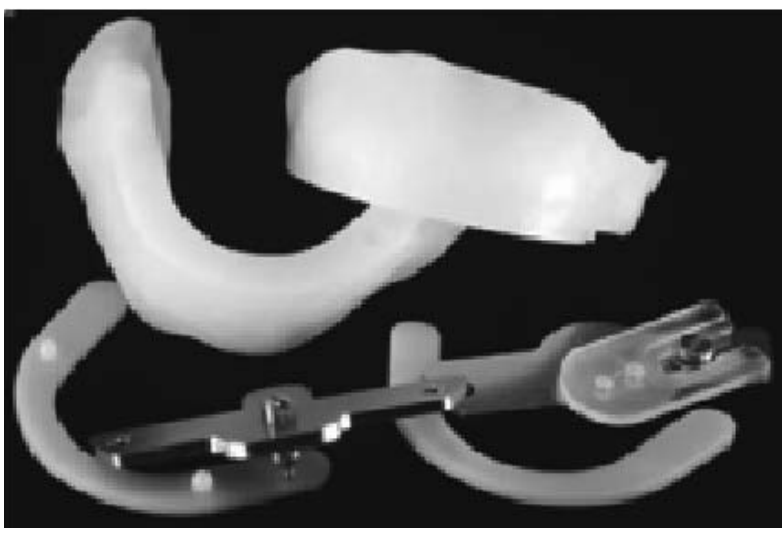

Rycina 3. Łyżki indywidualne, płytki rejestrujące (akrylowe) oraz urządzenie Gnatometr CAD

Figure 3. Custom trays, acrylic supports and gnathometer $C A D$

wykonywane są w sposób wirtualny w programie „Digital Denture Professional”. Po zeskanowaniu wycisków na nośniku zwarcia (centric tray) zostają zaprojektowane wirtualne modele bezzębnych szczęk w relacji takiej, jak zarejestrowane dane kliniczne. Połowa odległości między nimi wyznacza przebieg płaszczyzny protetycznej 3D, który jest modyfikowany w programie na podstawie danych z łuku twarzowego UTS CAD (istnieje możliwość wprowadzenia do programu kątów między zarejestrowaną klinicznie płaszczyzną a liniami Campera oraz międzyźreniczną). Kolejną czynnością jest proces frezowania łyżek indywidualnych górnej i dolnej z akrylu za pomocą maszyny wykorzystującej zjonizowane powietrze (Zenotec) oraz płytek rejestrujących (wykonanych z tego samego materiału) wykorzystywanych przy wyciskach czynnościowych przy ustach zamkniętych. Kolejnym narzędziem przygotowanym przez laboratorium jest Gnatometr CAD, który jest zbudowany $z$ dwóch płytek. Pierwsza montowana jest do łyżki górnej na zasadzie zatrzasku (wyfrezowane miejsca w łyżce i odpowiadające im wypustki w gnatometrze). Posiada śrubę zakończoną sztyftem, co umożliwia dokładne ustalenie wysokości zwarcia. Druga płytka, montowana do łyżki dolnej, umożliwia zarejestrowanie ruchów żuchwy oraz relacji centralnej (Rycina 3).

\section{Etap kliniczny}

$\mathrm{Na} ł y z ̇ k a c h ~ i n d y w i d u a l n y c h$, do których dołącza się płytki rejestrujące, po ich dostosowaniu w jamie ustnej, pobierane są przy ustach zamkniętych wyciski czynnościowe dwuwarstwowe przy użyciu masy poliwinylosiloksanowej. Pierwsza masa (Virtual Monophase) służy do czynnościowego kształtowania pobrzeży, druga o niskiej lepkości (Virtual Light Body Regular Set) umożliwia dokładne odwzorowanie szczegółów pola protetycznego. 
Następnie płytki akrylowe zostają zamienione na płytki rejestrujące (Gnatometr CAD). Po kontroli wysokości zwarcia oraz przeprowadzeniu koniecznych korekt za pomocą śruby (obniżenie lub podwyższenie sztyftu podpierającego w przypadku zmiany wymiaru pionowego zwarcia), wprowadza się do ust łyżki wyciskowe. Pacjent wykonuje ruchy żuchwą: do przodu, cofanie, przesunięcie w lewo, w prawo. Powstaje wykres na pokrytej tuszem płytce rejestrującej w postaci łuku gotyckiego. Na dolną płytkę rejestrującą nakłada się krążek z pleksiglasu i mocuje się go za pomocą śruby. Otwór krążka znajduje się ok. 0,5 mm poza wierzchołkiem strzały (co odpowiada relacji centralnej). Po wprowadzeniu łyżek do jamy ustnej pacjent zamyka usta tak, aby sztyft rejestracyjny trafit do otworu krążka z pleksiglasu. Następnie pomiędzy łyżki indywidualne zostaje wprowadzona masa do rejestracji. Na łyżce indywidualnej górnej lekarz zaznacza linię pośrodkową, kłów i uśmiechu, dobiera kolor i kształt zębów. Ponieważ proteza zostanie wykonana w technologii CAD/CAM, nie ma konieczności wykonywania uszczelnienia tylnego obrzeża protezy w okolicy linii AH. Jednakże, gdy lekarz czuje taką potrzebę, można ten proces wykonać za pomocą aplikacji odpowiedniej ilości wosku na tylną granicę wycisku, którego grubość odpowiada podatności błony śluzowej w tej okolicy (co odpowiada uszczelnieniu pierwotnemu wycisku czynnościowego w tradycyjnych protezach).

\section{Etap laboratoryjny}

Wyciski czynnościowe wraz z zarejestrowaną pozycją szczęki do żuchwy zostają poddane skanowaniu (Rycina 4), tworzone są wirtualne modele szczęki i żuchwy, a trójwymiarowa płaszczyzna zgryzu ustalana na podstawie danych z łuku UTS CAD (Rycina 5). W programie dostępne są obszerne biblioteki kształtów zębów (Rycina 6), a ich ustawienie oparte jest o standardowe wyznaczniki, takie jak krzywa Spee czy Monsona. Możliwa jest również indywidualizacja ustawienia zębów oraz modelowanie płyty protezy. Okluzja pozacentralna może być zweryfikowana w artykulatorze wirtualnym, co umożliwia wykrycie przedwczesnych kontaktów okluzyjnych. Po zakończeniu projektu $z$ jednolitego materiału PMMA w technologii CAM zostaje wyfrezowana proteza próbna, która odpowiada w proporcji 1:1 docelowej protezie.

\section{Etap kliniczny}

Etap kontroli protez próbnych jest identyczny jak w przypadku metody konwencjonalnej. Lekarz sprawdza zasięg płyty protezy, ustawienie zębów sztucznych, estetykę, fonetykę, okluzję centralną, pozacentralną itd., przekazuje technikowi infor-

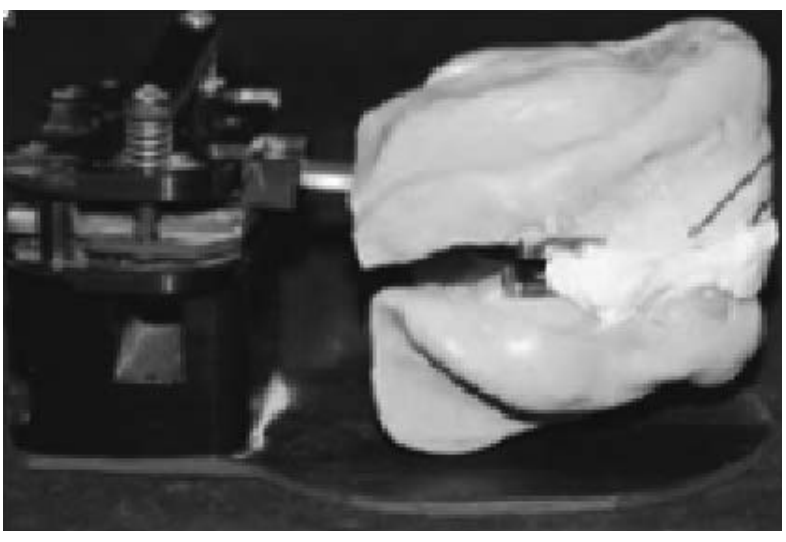

Rycina 4. Wyciski czynnościowe oraz zarejestrowana relacja żuchwy do szczęki w skanerze optycznym

Figure 4. Prepared functional impressions and bite registration for the scanning procedure

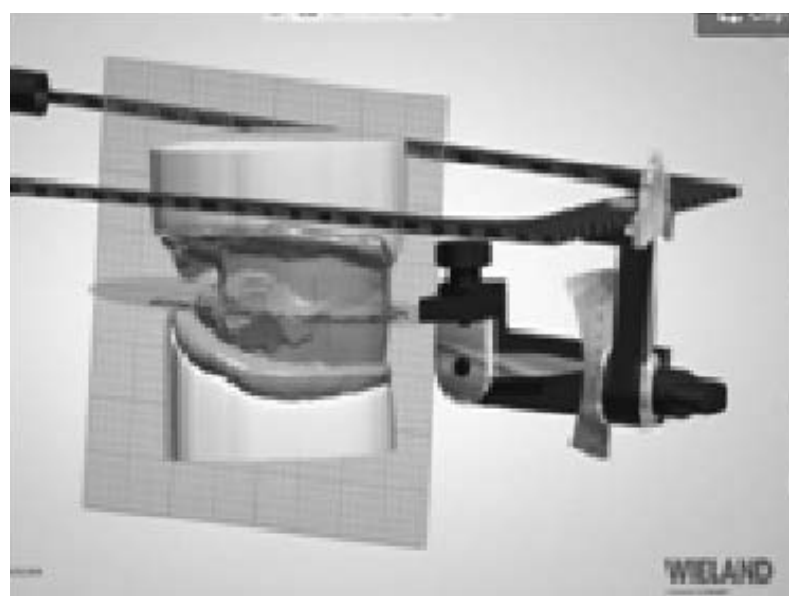

Rycina 5. Trójwymiarowa płaszczyzna zgryzu ustalana na podstawie danych z cyfrowego łuku twarzowego UTS CAD

Figure 5. The final occlusal plane for the denture design is defined on the values from UTS CAD

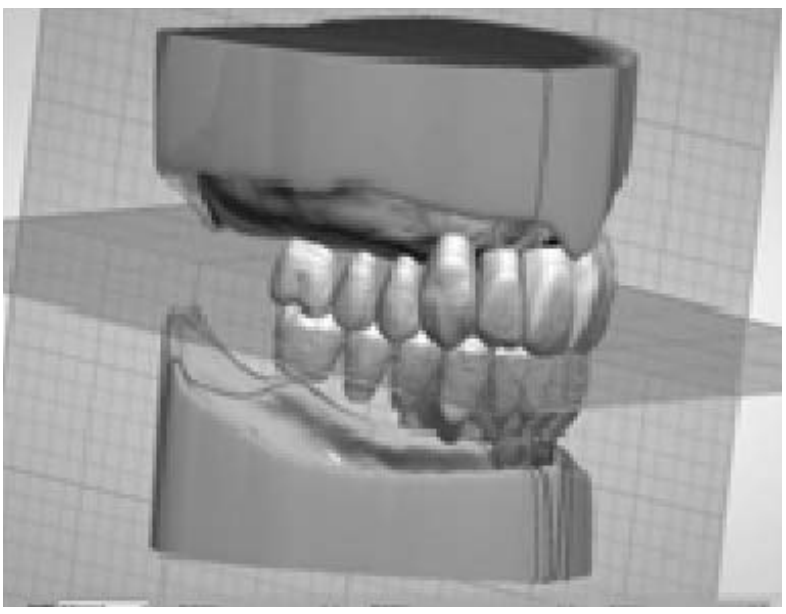

Rycina 6. Wybór zębów z biblioteki dostępnej w programie Digital Denture Professional

Figure 6. Teeth are chosen from a library of denture teeth in program Digital Denture Professional 
macje o akceptacji bądź potrzebie wykonania niezbędnych korekt przed wykonaniem docelowych protez.

\section{Etap laboratoryjny}

Kolejnym etapem jest proces frezowania gotowej płyty protezy za pomocą frezarki Zenotec z wcześniej spolimeryzowanego krążka żywicy akrylowej (IvoBase) (Rycina 7). Proces ten przebiega w 2 etapach. W pierwszym następuje obróbka powierzchni górnej protezy niekontaktującej się z podłożem protetycznym, z uwzględnieniem otworów, w których zostaną umieszczone zęby sztuczne za pomocą systemu łączącego IvoBase CAD Bond. W tym celu technik przygotowuje wcześniej specjalny szablon, aby mieć pewność, że zęby zostaną umieszczone we właściwy sposób. Po tych czynnościach następuje frezowanie powierzchni dośluzówkowej. Obróbka końcowa protez odbywa się w sposób konwencjonalny.

\section{Etap kliniczny}

Kontrolę i korektę gotowych protez całkowitych przeprowadza się w sposób nie odbiegający od metod tradycyjnych.

\section{Avadent (Global Dental Science LLC.)}

Aby można było zastosować u pacjenta protezy całkowite Avadent, musi on odbyć zgodnie z zaleceniami producenta 2 wizyty kliniczne [18]:

1. Pobranie wycisków czynnościowych, zarejestrowanie relacji żuchwy do szczęki w relacji centralnej, wyznaczenie przebiegu płaszczyzny protetycznej, dobór kształtu i koloru zębów sztucznych oraz pozycji zębów przednich w przyszłym uzupełnieniu protetycznym.

2. Oddanie protez.

W systemie tym stosuje się specjalny zestaw, aby odpowiednio przeprowadzić ww. etapy. W pierwszej kolejności pobiera się wycisk za pomocą masy poliwinylosiloksanowej na poprzedniej

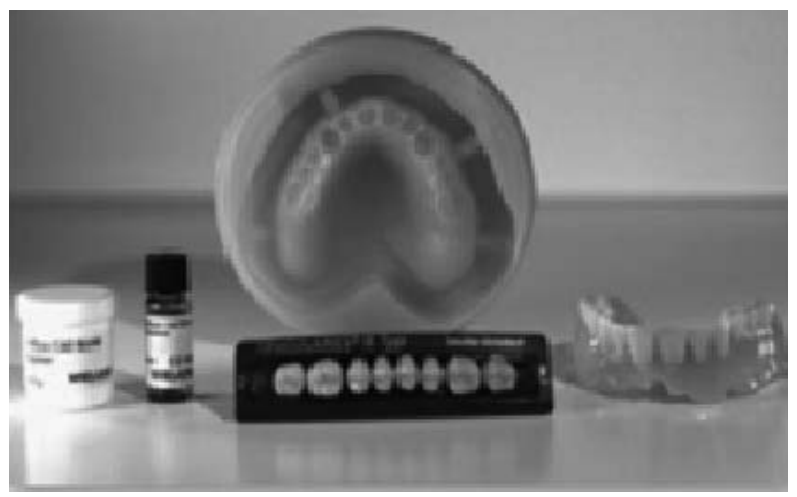

Rycina 7. Wykonanie gotowej protezy

Figure 7. Finalizing the dentures

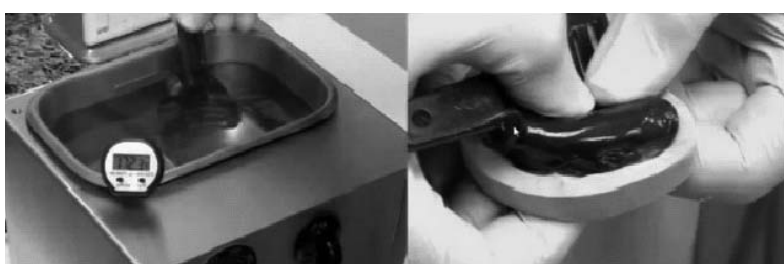

Rycina 8. Korekta łyżki w gorącej wodzie i na modelu Figure 8. Adapting the tray in a water bath and to the putty cast
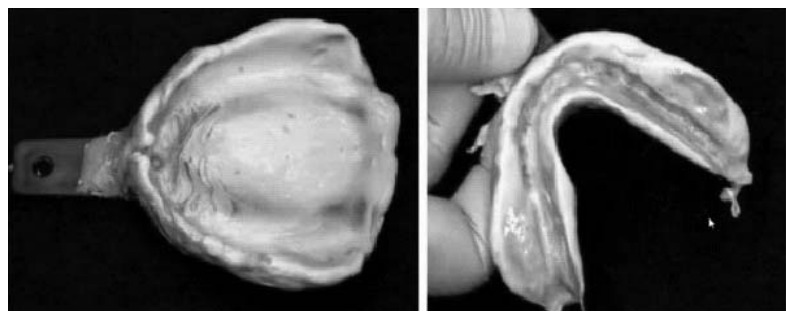

Rycina 9. Wyciski czynnościowe dwuwarstwowe szczęki i żuchwy

Figure 9. Maxillary and mandibular definitive impressions

protezie pacjenta, a następnie odlewa model (o ile lekarz dysponuje gipsem w swoim gabinecie). Jeśli pacjent nie korzystał wcześniej z uzupełnień, należy pobrać wycisk anatomiczny masą alginatową i odlać na jego podstawie model pomocniczy. Następnie stosuje się łyżkę, która ulega uplastycznieniu w wodzie o temperaturze 80 stopni Celsjusza, dzięki czemu można ją dowolnie wydłużać (Rycina 8) lub skracać, np. za pomocą frezu. Po korekcie i ukształtowaniu łyżki na modelu oraz w jamie ustnej pacjenta pobiera się wycisk czynnościowy dwuwarstwowy z kształtowaniem obrzeża za pomocą masy silikonowej o konsystencji „putty body", z następnie z użyciem masy poliwinylosiloksanowej „light body” (Rycina 9).

\section{Rejestracja relacji żuchwy do szczęki}

Firma Avadent zaprojektowała specjalny przyrząd do pomiaru poszczególnych cech anatomicznych $\mathrm{u}$ danego pacjenta, nazwany AMD (anatomical measuring device), który umożliwia ustalenie pożądanego wymiaru pionowego zwarcia (OVD), rejestrację relacji centralnej $w$ formie łuku gotyckiego za pomocą rysika i płytki, prawidłowej wysokości górnej wargi, jej podparcia za pomocą sześciu zębów przednich i orientacji poziomej płaszczyzny zgryzu. AMD składa się z dwóch części: łyżki górnej $z$ centralnie regulowanym rysikiem - regulowanym elementem rejestrującym podparcie wargi górnej oraz łyżki dolnej ze stolikiem rejestrującym (Rycina 10). Obie łyżki są powlekane środkiem adhezyjnym. Pobierany jest na nich wycisk (np. za pomocą masy silikonowej „light body), któ- 


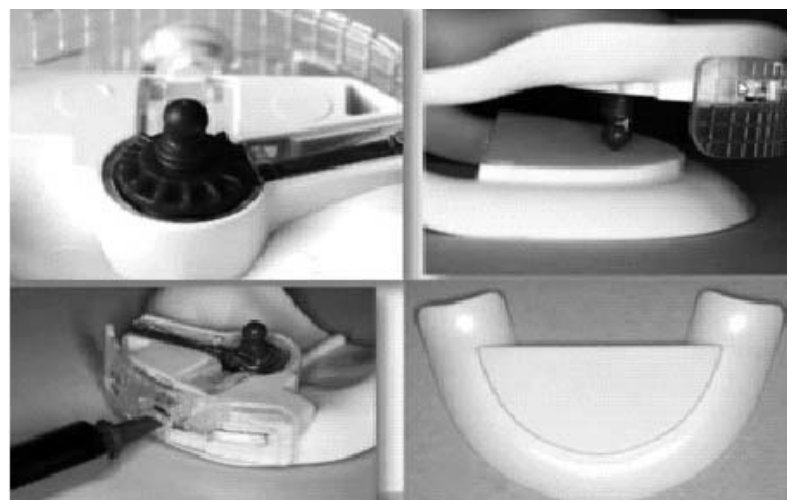

Rycina 10. AMD - przyrząd pomiaru cech anatomicznych Figure 10. $A M D$ - anatomical measuring device

ry służy wyłącznie do stabilnego utrzymania ich w jamie ustnej podczas zabiegu rejestracji zwarcia centralnego i nie jest wykorzystywany $w$ toku dalszych procedur. Pionowy wymiar zwarcia rejestruje się za pomocą rylca, który jest regulowany do momentu jego kontaktu ze stolikiem rejestrującym metodami konwencjonalnymi (np. anatomofizjologiczną, anatomiczną, antropometryczną itp.). Wymiar ten, jeśli jest akceptowalny, można też przenieść z poprzednich protez. Następnie, przy ustalonej wysokości zwarcia, pacjent wykonuje ruchy boczne oraz przednio-tylne, „rysując” na powierzchni stolika graniczne pozycje, w których może znaleźć się żuchwa. Powstaje wykres graficzny w formie strzały, w której trzon prezentuje ruchy przednio-tylne żuchwy, ramiona ruchy boczne, a ostrze jest pozycją, jaką przyjmuje żuchwa, kiedy głowy znajdują się w maksymalnie dotylnym położeniu.

Równoległość płaszczyzny protetycznej względem linii źrenic uzyskuje się dzięki specjalnej linijce, którą dołącza się do łyżki górnej AMD (Rycina 11). Następnie na elemencie służącym do rejestracji podparcia wargi górnej zaznacza się linię pośrodkową zębów sztucznych w protezie oraz linię uśmiechu. Kształt zębów dobierany jest za pomocą specjalnych szablonów, do wnętrza których wprowadza się niewielką ilość materiału typu „flow" i umocowuje się na zewnętrznej stronie elementu podpierającego wargę górną, uwzględniając linię uśmiechu oraz pośrodkową twarzy (Rycina 12) Możliwe jest określenie na tych formach również wysokości szyjek zębowych. Po sprawdzeniu końcowym wszystkich zarejestrowanych pomiarów łączy się oba elementy AMD za pomocą materiału silikonowego, w położeniu odpowiadającym szczytowi łuku gotyckiego. W płytce dolnej lekarz wykonuje niewielki otwór, w który wchodzi rylec łyżki górnej AMD (Rycina 13).

Zdezynfekowane wyciski czynnościowe oraz AMD przesyła się do laboratorium Global Dental

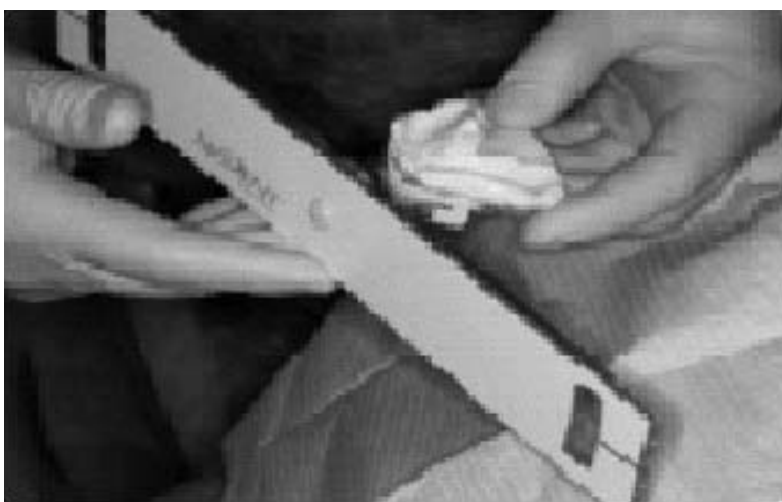

Rycina 11. Linijka dołączona do łyżki górnej AMD

Figure 11. Avadent ruler being attached to the maxillary $A M D$

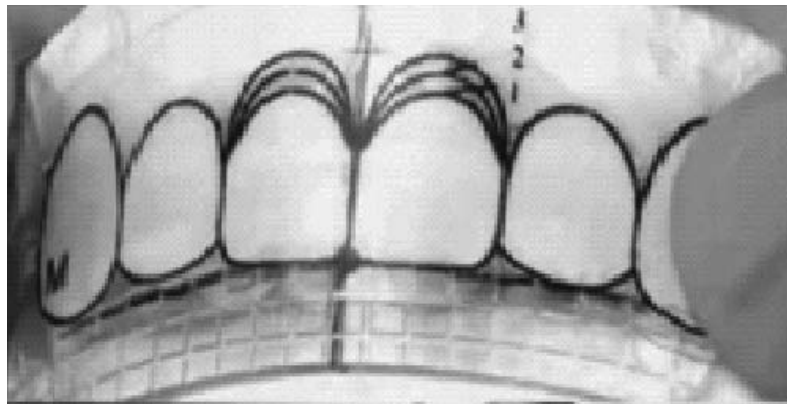

Rycina 12. Szablon przyklejony do elementu podpierającego wargę górną

Figure 12. Luting selected tab with flowable light-cured composite resin

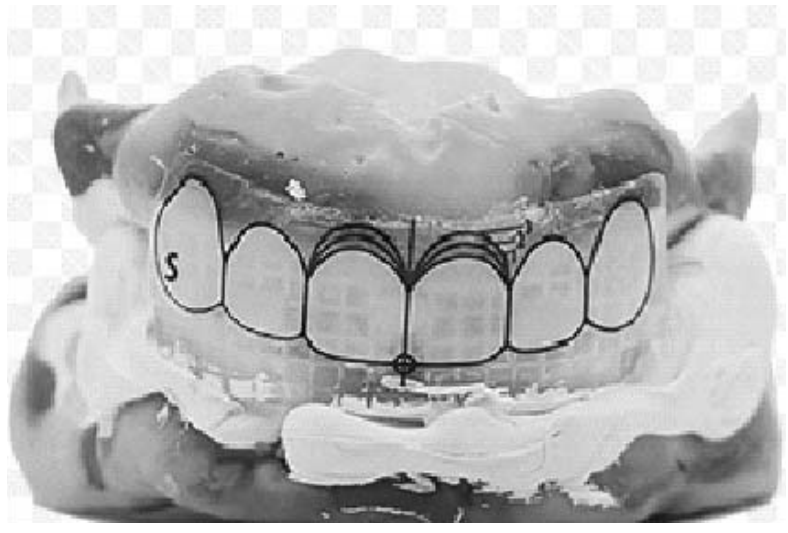

Rycina 13. Relacja żuchwy do szczęki zarejestrowana przy pomocy AMD wraz z szablonem

Figure 13. AMD's jaw relation record with mold tab

Science LLC, gdzie są poddawane procesowi skanowania laserowego. $W$ ten sposób uzyskiwane są modele wirtualne, dane morfologiczne pacjenta są analizowane $w$ formie elektronicznej i służą do projektowania przyszłych protez. Wykonuje się je za pomocą skrawania wcześniej spolimeryzowanego krążka żywicy akrylowej, pozostawiając 


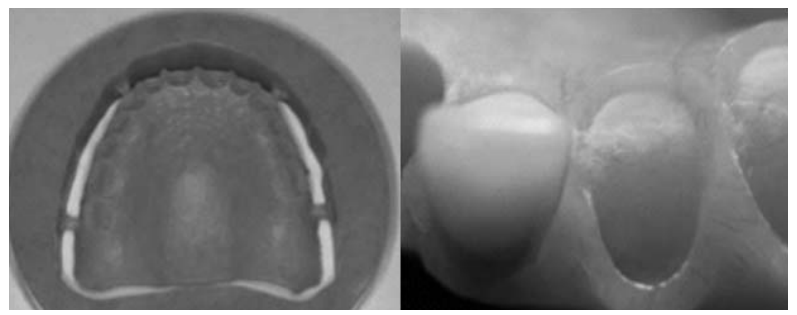

Rycina 14. Frezowanie protezy całkowitej, wklejanie zębów sztucznych

Figure 14. Milled denture base and teeth placed in milled recess

otwory, w których następnie zostaną przyklejone zęby sztuczne (Rycina 14).

\section{Kontrola protez próbnych (opcjonalnie)}

Lekarz kontroluje woskowa protezę próbną, która ma bazę akrylową wykonaną w technologii CAD / CAM, natomiast zęby są ustawione w wosku (ATI - advance try-in denture), dzięki czemu w razie konieczności można zmienić ich ustawienie. Inną opcją jest wykonanie modelu stereolitograficznego przyszłych protez w całości z materiału PMMA (BTI - Bouma try-in).

\section{Oddanie protez}

Wizyta ta jest podobna jak w przypadku oddania uzupełnień wykonanych metodą konwencjonalną. Lekarz sprawdza wykonawstwo laboratoryjne, okluzję centralną i pozacentralną, wykonuje niezbędne korekty, przekazuje zalecenia pacjentowi, ustala termin wizyt kontrolnych.

\section{Dentca $^{\mathrm{TM}}$ (Dentca Inc.)}

W celu zastosowania u pacjenta protez całkowitych Avadent, musi on przejść zgodnie z zaleceniami producenta 2 wizyty kliniczne [18]:

\section{Wizyta 1-pobranie wycisków czynnościowych} oraz rejestracja relacji żuchwy do szczęki

Firma oferuje specjalny zestaw łyżek o rozmiarach małych, średnich, dużych i bardzo dużych, używanych w zależności od warunków anatomicznych. Łyżki dwuczłonowe z odłączaną częścią tylną są termoplastyczne (Rycina 15). W przypadku przekraczania lub nieobejmowania swoim zasięgiem pola protetycznego możliwe jest ich skrócenie (np. za pomocą frezu) lub rozszerzenie pod wpływem ciepłej wody. Pobierany jest wycisk czynnościowy dwuwarstwowy, pierwszy za pomocą masy poliwinylosiloksanowej o konsystencji „putty”, z czynnościowym kształtowaniem pobrzeży, natomiast druga warstwa za pomocą masy „light”. Tylną granicę wycisku, niezbędną do uszczelnienia, lekarz

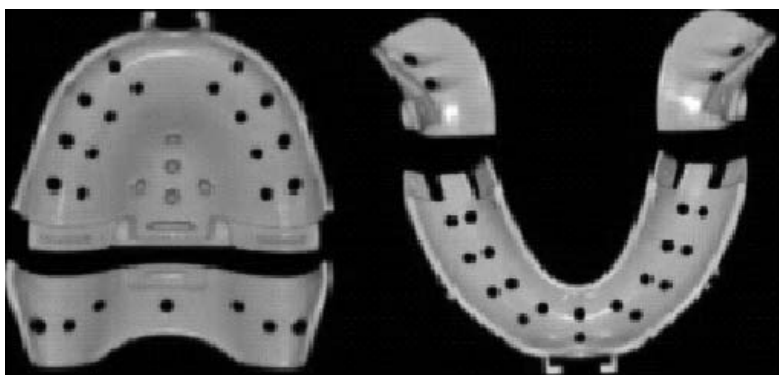

Rycina 15. Dwuczęściowe łyżki: górna i dolna

Figure 15. Detachable stock trays: upper and lower

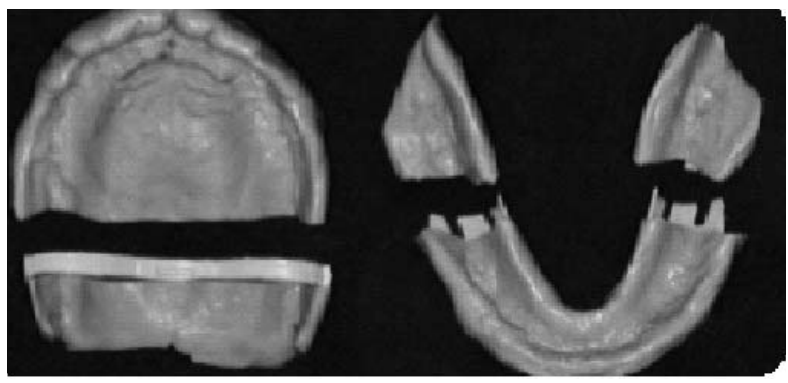

Rycina 16. Wyciski czynnościowe na rozdzielonych częściach łyżek

Figure 16. Maxillary and mandibular definitive impressions

zaznacza ołówkiem. Kolejno nakładana jest odpowiednia ilość wosku odpowiadająca podatności błony śluzowej tej okolicy.

\section{Rejestracja relacji żuchwy do szczęki}

Przed wykonaniem tego zabiegu, przecina się za pomocą skalpela wycisk czynnościowy w miejscu, gdzie można rozłączyć łyżki, na tyle dokładnie, aby uniknąć jego uszkodzenia (Rycina 16). Następnie do łyżki górnej montuje się płytkę rejestrującą, na której jest wykreślany łuk gotycki, a do dolnej rylec (Rycina 17).

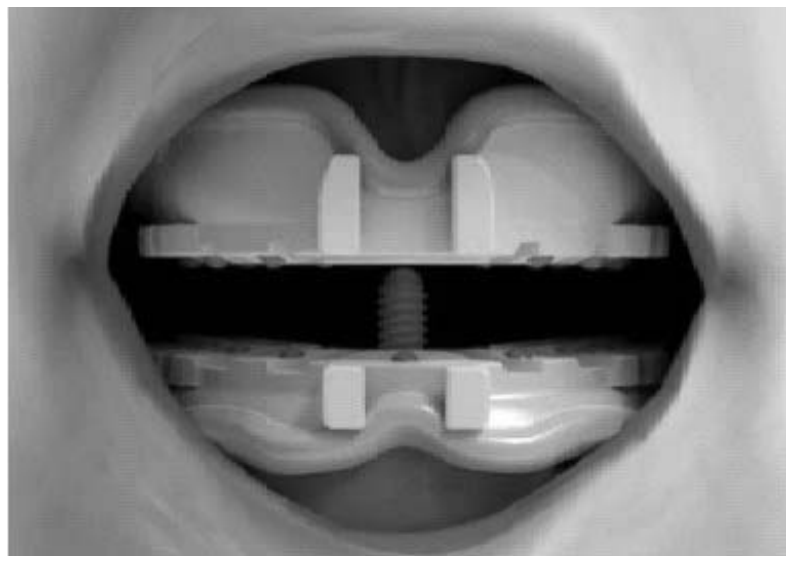

Rycina 17. Rylec zamontowany do łyżki dolnej

Figure 17. Adjustable stylus being slotted into the mandibular tray 


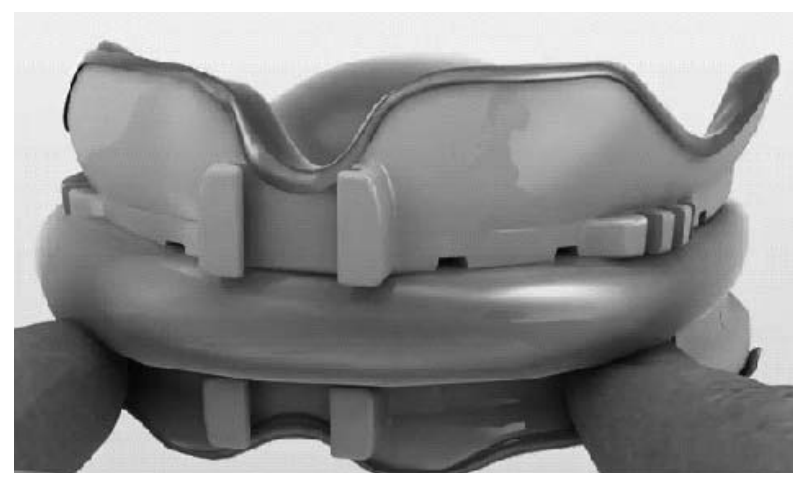

Rycina 18. Zarejestrowana relacja żuchwy do szczęki Figure 18. Jaw relation record

Pozostałe etapy są analogiczne jak w systemie Avadent. Przy doborze zębów sztucznych lekarz posługuje się specjalną linijką wargową, która służy do pomiaru długości wargi górnej w spoczynku oraz odległości jej dolnej granicy od brodawki przysiecznej. Silikonowy materiał rejestrujący jest wstrzykiwany pomiędzy obie łyżki ustawione względem siebie w zarejestrowanej wcześniej relacji centralnej (Rycina 18).

Następnie taki rejestrat połączony z wyciskami czynnościowymi jest przesyłany do laboratorium i poddawany procesowi skanowania. Po zaprojektowaniu cyfrowym przyszłych protez, dane są przekazywane do urządzenia laserowego, który tworzy próbne protezy za pomocą szybkiego wykonywania prototypów w formie modelu stereolitograficznego, natomiast gotowe protezy wykonuje się tradycyjną techniką puszkowania akrylu.

\section{Wizyta 2 - oddanie protez}

Wizyta ta jest taka sama, jak w przypadku oddania uzupełnień Wieland dental, Avadent, jak i wykonanych metodą konwencjonalną.

\section{Ceramill FDS (full denture system)}

Ceramill (FDS) (Amann Girrbach AG, Koblach, Austria) jest systemem służącym do projektowania i wykonywania protez całkowitych w laboratorium dentystycznym. W przeciwieństwie do metod opisywanych wcześniej nie posiada specjalnych narzędzi, którymi dysponuje lekarz podczas pracy klinicznej. Poszczególne etapy podczas pierwszych 3 wizyt klinicznych przeprowadza się w sposób tradycyjny (pobranie wycisków anatomicznych, czynnościowych, rejestracja zwarcia centralnego, dobór koloru i kształtu zębów sztucznych, wyznaczenie linii pomocniczych). Po zaartykulowaniu modeli w artykulatorze Amann Girrbach AG każdy z nich najpierw jest skanowany oddzielnie, a nastepnie ich wzajemna relacja przestrzenna zostaje przeniesiona do specjalnego przenośnika (Ceramill Transferkit), który umieszcza się w skanerze
(Ceramill Map40). W ten sposób ustawienie modeli względem siebie zostanie odwzorowane w postaci cyfrowej. Projektowanie konstrukcji protezy rozpoczyna się od oznakowania specjalnych punktów na modelach, na podstawie których program automatycznie ustala linię pośrodkową, położenie zębów przednich, kształt, wielkość w zależności od miejsca w zwarciu. Istnieje również możliwość wirtualnego modelowania płyty protezy. Wszystkie te dane mogą być dowolnie zmienione w laboratorium oraz przez lekarza po przesłaniu danych do gabinetu. Po zaakceptowaniu następuje proces skrawania płyty protezy z różowego wosku przy pomocy chłodzonej wodą czteroosiowej frezarki (Ceramill motion 2), z pozostawieniem otworów dopasowany kształtem do wybranych zębów, które zostaną w nich później mechanicznie umieszczone. Pozostałe etapy kliniczne i laboratoryjne przeprowadza się są w sposób tradycyjny.

\section{Protezy szkieletowe}

\section{Projektowanie protez szkieletowych}

Niewiele artykułów opublikowanych w specjalistycznych czasopismach dotyczy możliwości wykorzystania technologii CAD/CAM w projektowaniu protez szkieletowych [19-22]. Williams i wsp. [19] przedstawili metodę, w której zeskanowany model roboczy (uzyskany z odlewania z gipsu twardego $z$ tradycyjnego wycisku) jest zaimportowany bezpośrednio do oprogramowania (Freeform ${ }^{\mathrm{TM}}$ ) dzięki połączeniu ze skanerem optycznym (Comet 250). W programie uzyskiwany jest trójwymiarowy model. Korzystając z różnych funkcji, operator wykonuje wirtualną analizę paralelometryczną, wyznaczając powierzchnie retencyjne i prowadzące, pośrednie i wprowadzające, analizę bocznych powierzchni pola protetycznego oraz ich jakości. Po wykonaniu tych czynności można rozpocząć finalną fazę projektowania. Dostępny jest pełny komplet łączników dużych, małych, utrzymywaczy bezpośrednich, pośrednich, podparć. Każda część musi mieć odpowiednią grubość, zgodnie ze swoim przeznaczeniem [23]. Można zaprojektować również akrylowy element retencyjny, korzystając z szeregu opcji siatki i modyfikacji powierzchni, tak jak w przypadku protez szkieletowych wykonanych metodą tradycyjną.

\section{Wykonywanie szkieletu protezy szkieletowej w systemie CAD/CAM}

Cyfrowy projekt szkieletu przyszłego uzupełnienia jest przesyłany do urządzenia (AM250), w którym dochodzi do wytwarzania przyrostowego (AM) [12]. W uproszczeniu: maszyna utrwala cienką warstwę proszku metalowego ze stopu chromo-kobaltowego (o grubości 20 mikrometrów) za pomocą bardzo 
wąskich wiązek lasera. W ten sposób warstwa po warstwie powstaje szkielet protezy szkieletowej. Pozostałe etapy kliniczne i laboratoryjne nie różnią się od etapów metody konwencjonalnej.

\section{Zalety protez ruchomych wykonanych w CAD/CAM}

Do niewątpliwych zalet tego rodzaju technologii należy: zmniejszona liczba wizyt, brak skurczu polimeryzacyjnego tworzywa akrylowego, a co za tym idzie zmniejszenie możliwości kolonizacji mikroorganizmów na powierzchni protez [24], łatwe odtworzenie protezy (np. w przypadku zgubienia przez pacjenta) $z$ danych zapisanych w programie komputerowym, możliwość wykorzystania protezy próbnej ( $w$ formie modelu stereolitograficznego) jako szablonu radiologicznego w przyszłości, gdy pacjent zdecyduje się na leczenie implantoprotetyczne, mniejsza kolonizacja protezy przez szczepy Candida albicans, redukcja kosztów związanych z wykorzystaniem materiałów i sprzętu laboratoryjnego niezbędnego w przypadku zastosowania konwencjonalnych metod wykonawstwa, bardzo dobra retencja i stabilizacja w ocenie lekarzy i pacjentów [25], możliwość zaprojektowania i wykonania dokładniejszej protezy całkowitej natychmiastowej [26].

\section{Ograniczenia technologii CAD/CAM przy wykonywaniu protez ruchomych}

Niemożność wykorzystania technologii w przypadku dużych wad szkieletowych, znacznej resorpcji wyrostka zębodołowego szczęki i części zębodołowej żuchwy, niezborności ruchów żuchwy [15], względnie mała dostępność technologii [27], wizyta kontroli protez próbnych pozostanie niezbędnym etapem leczenia protetycznego pomimo zaleceń, aby traktować ją opcjonalnie [28], trudności kliniczne i laboratoryjne w uzyskaniu okluzji obustronnie wybalansowanej w protezach [29].

\section{Podsumowanie}

Technologia CAD/CAM, która od kilkunastu lat jest używana w projektowaniu i wytwarzaniu protez stałych, współcześnie jest wprowadzana do stosowania także w przypadku laboratoryjnego wykonywania protez ruchomych. Ostatnio dostępne stały się narzędzia cyfrowe, umożliwiające szybkie i przewidywalne leczenie pacjentów bezzębnych. Pomimo wielu zalet (takich jak lepsze dopasowanie płyty protezy, eliminacja skurczu polimeryzacyjnego, mniejsza porowatość tworzywa i ograniczona kolonizacja przez mikroorganizmy [30], jakie są z nią związane i które umożliwiają skrócenie procesu leczniczego), metoda ta na dzień dzisiejszy ma szereg ograniczeń. Póki co nie jest powszechnie stosowana, stąd jedynie nieliczne publikacje w piśmiennictwie. Jednakże konwencjonalne wykonawstwo kliniczne i laboratoryjne protez ruchomych ze względu na dużą liczbę etapów, w których uczestniczy lekarz stomatolog i technik, również nie jest wolne od błędów. W przyszłości, gdy zwiększy się dostępność tej technologii, potrzebne jest przeprowadzenie kontrolowanego randomizowanego badania klinicznego w celu ustalenia, czy uzupełnienia te mogą stanowić alternatywę dla protez ruchomych wykonywanych konwencjonalnymi metodami.

Wszystkie zdjęcia umieszczone w artykule zostały opublikowane za zgodą i dzięki uprzejmości firmy Ivoclar Vivadent, Avadent oraz Dentca ${ }^{\mathrm{TM}}$.

\section{Oświadczenia}

Oświadczenie dotyczące konfliktu interesów

Autorzy deklarują brak konfliktu interesów w autorstwie oraz publikacji pracy.

\section{Źródła finansowania}

Autorzy deklarują brak źródeł finansowania.

\section{Piśmiennictwo}

[1] Jacob RF. The traditional therapeutic paradigm: complete denture therapy. J Prosthet Dent. 1998;79:6-13.

[2] Bidra AS, Taylor TD, Agar JR. Computer-aided technology for fabricating complete dentures: Historical background, current status and future perspectives. J Prosthet Dent. 2013;109:361-6.

[3] Lima JM, Anami LC, Araujo RM, Pavanelli CA. Removable partial dentures: Use of rapid prototyping. J Prosthodont. 2014;23:588-91.

[4] Beuer F, Schweiger J, Edelhoff D. Digital dentistry: An overview of recent developments for CAD/CAM generated restorations. Br Dent J. 2008;204:505-11.

[5] Miyazaki T, Hotta Y, Kunii J, Kuriyama S, Tamaki Y. A review of dental CAD/CAM: current status and future perspectives from 20 years of experience.

[6] Maeda Y, Minoura M, Tsutsumi S, Okada M, Nokubi T. A CAD/CAM system for removable denture. Part I: Fabrication of complete dentures. Int J Prosthodont. 1994;7:17-21.

[7] Kanazawa M, Inokoshi M, Minakuchi S, Ohbayashi N. Trial of a CAD/CAM system for fabricating complete dentures. Dent Mater J. 2011;30:93-6.

[8] Busch M, Kordass B. Concept and development of a computerized positioning of prosthetic teeth for complete dentures. Int J Comput Dent. 2006;9:113-20.

[9] Inokoshi M, Kanazawa M, Minakuchi S. Evaluation of a complete denture trial method applying rapid prototyping. Dent Mater J. 2012;31:40-6.

[10] Kawahata N, Ono H, Nishi Y, Hamano T, Nagaoka E. Trial of duplication procedure for complete dentures by CAD/ CAM. J Oral Rehabil. 1997;24:540-8.

[11] Bidra AS. The 2-visit CAD/CAM implant-retained overdenture: a clinical report. J Oral Implantol. 2014;40:722-8.

[12] Williams RJ, Bibb R, Rafik T. A technique for fabricating patterns for removable partial denture frameworks using digitized casts and electronic surveying. J Prosthet Dent. 2004;91:85-8.

[13] Williams RJ, Bibb R, Eggbeer D. CAD/CAM in the fabrication of removable partial denture frameworks: a virtual method of surveying 3D scanned dental casts. Quintessence J Dent Technol. 2004;2:268-76.

[14] Han J, Wang Y, Lü P. A preliminary report of designing removable partial denture frameworks using a specifi- 
cally developed software package. Int J Prosthodont. 2010;23:370-5.

[15] Kattadiyil MT, Goodacre CJ, Baba NZ. CAD/CAM complete dentures: a review of two commercial fabrication systems. J Calif Dent Assoc. 2013;41:407-16.

[16] Majewski St.: Współczesna protetyka stomatologiczna. Podstawy teoretyczne i praktyka kliniczna. Rehabilitacja protetyczna pacjentów bezzębnych z zastosowaniem protez całkowitych. Procedura postępowania kliniczno-laboratoryjnego z zastosowaniem biofunkcjonalnego systemu protetycznego (BPS)). Elsevier Urban \& Partner, Wrocław. 2014, 237-241.

[17] Venezla P, Lacasella P. Cyfrowe protezy całkowite. Pierwsze kliniczne i techniczne doświadczenia z Digital Denture System (Wieland Dental). TPS, 2017;3:71-78.

[18] Bidra AS, Taylor TD, Agar JR. Computer-aided technology for fabricating complete dentures: Systematic review of historical background, current status, and future perspectives. J Prosthet Dent. 2013;109:361-6.

[19] Williams RJ, Bibb R, Eggbeer D. CAD/CAM-fabricated removable partial-denture alloy frameworks. Pract Proced Aesthet Dent. 2008 Jul;20(6):349-51.

[20] Bibb RJ, Eggbeer D, Williams RJ, Woodward A. Trial fitting of a removable partial denture framework made using computer-aided design and rapid prototyping techniques. Proc Inst Mech Eng H. 2006 Oct;220(7):793-7.

[21] Eggbeer D, Bibb R, Williams R. The computer-aided design and rapid prototyping fabrication of removable partial denture frameworks. Proc Inst Mech Eng H. 2005 May;219(3):195-202.

[22] Williams RJ, Bibb R, Eggbeer D, Collis J. Use of CAD/ CAM technology to fabricate a removable partial denture framework. J Prosthet Dent. 2006 Aug;96(2):96-9.

[23] Guo-Dong Y, Wen-He L, Dai N. The Computer-Aided Design and Rapid Prototyping Fabrication of Removable Partial Denture Framework. Paper Presented at: Computer Science and Information Technology, 2009. ICCSIT 2009. 2nd IEEE International Conference on 2009.
[24] Mehmet Selim Bilgin, Ebru Nur Baytaroğlu, Ali Erdem, Erhan Dilber Eur J Dent. 2016 Apr-Jun; 10(2): 286-291. Doi: 10.4103/1305-7456.178304.

[25] Bidra AS, Taylor TD, Agar JR. Computer-aided technology for fabricating complete dentures: Systematic review of historical background, current status, and future perspectives. J Prosthet Dent. 2013;109:361-6.

[26] Neumeier TT, Neumeier H. Digital: A clinical report of two patients. J Prosthet Dent. 2016 Sep;116(3):314-9.

[27] Mehmet Selim Bilgin, Ebru Nur Baytaroğlu, Ali Erdem, Erhan Dilber A fabrication Eur J Dent. 2016 Apr-Jun; 10(2): 286-291. Doi: 10.4103/1305-7456.178304.

[28] Schwindling FS, Stober T. A comparison of two digital techniques for the fabrication of complete removable dental prostheses: A pilot clinical study. J Prosthet Dent. 2016 Nov;116(5):756-763.

[29] Baba NZ, Goodacre CJ, Kattadiyil MT. CAD/CAM removable prosthodontics. In: Masri R, Driscoll CF, editors. Clinical applications of digital technology. Hoboken: John Wiley \& Sons, Inc; 2015.

[30] Lisiakiewicz W, Mierzwińska-Nastalska E. Protezy całkowite wykonywane w oparciu o technologię CAD/CAM. Protet Stomatol. 2016;LXVI(4):307-310.

Zaakceptowano do edycji: 2017-03-12 Zaakceptowano do publikacji: 2017-04-22

\author{
Adres do korespondencji: \\ Sebastian Farmas \\ Kuźnicy Kołłątajowskiej 13B/48 \\ 31-234 Kraków \\ tel.: +48664035 345 \\ e-mail: sebastian.farmas@interia.pl
}

